\title{
Production of Formosa papaya seedlings irrigated with wastewater and application of biostimulant
}

\author{
Anna Paula Marques Cardoso $1 *\left(\bullet\right.$,Elias Ariel Moura ${ }^{2} \odot$, Luana Mendes Oliveira ${ }^{2} \odot$, \\ Luciana Medeiros de Freitas Mendonça ${ }^{3}$ (D) Francisco Romário Andrade Figueiredo2(D, \\ Wilma Freitas Celedônio ${ }^{3}$ (D) Vander Mendonça² \\ 'Federal Rural University of Rio Grande do Norte, Macaiba, Brazil \\ ${ }^{2}$ Federal Rural University of Semi-arid, Mossoró, Brazil \\ ${ }^{3}$ Federal University of Campina Grande, Patos, Brazil \\ ${ }^{4}$ Federal University of Paraíba, Areia, Brazil \\ "Corresponding author; e-mail: annaagro2012@gmail.com
}

\begin{abstract}
Papaya (Carica papaya L.) is one of the leading fruit trees in Brazil, mainly in the Northeast region. However, some regions suffer from water scarcity, making wastewater reuse a viable alternative for crop production. Also, biostimulants may be used to maximize papaya growth and development. Thus, this work aimed to evaluate the use of Acadian ${ }^{\circledR}$ biostimulant in the growth of Formosa papaya seedlings irrigated with different concentrations of fish-farming wastewater. The experiment was block randomized in a $2 \times 5$ factorial scheme, use and non-use of biostimulant and five concentrations of wastewater $(0,10,20,30$, and $40 \%$ ) diluted in potable water, with four replicates. Qualitative data were compared by t-test at 5\% probability, and quantitative data were submitted to regression analysis. Results showed that high concentrations of wastewater negatively affect the production of Formosa papaya seedlings. Acadian ${ }^{\circledR}$ negatively influences plant height, number of leaves, and the ratio between shoot and root. However, the seaweed biostimulant positively influenced the chlorophyll content index.
\end{abstract}

Keywords: Ascophyllum nodosum, Carica papaya L., initial growth, water reuse

\section{Introduction}

Papaya (Carica papaya L.) is an herbaceous plant from South America that has been adapted to tropical and subtropical climates and get worldwide economic importance (Figueiredo et al., 2018). In Brazil, the Northeast region is the leading producer, mainly in Bahia, Espirito Santo, and Rio Grande do Norte States (Anuário Brasileiro de Fruticultura, 2018).

Some environmental factors, such as water scarcity may be a limiting factor for the growth and development of papaya, like in the Brazilian semiarid region, where the climate is characterized by low rainfall and relative humidity, and high temperatures. In this sense, the use of wastewater diluted with supply water for irrigation can become advantageous due to water scarcity and the dispute over the priority use of drinking water (Oliveira et al., 2017).

Wastewater from different sources has been used successfully for irrigation of many crops such as Eucalyptus urophylla L. (Batista et al., 2014), Helianthus annuus L. (Oliveira et al., 2017) and Raphanus sativus L. (Dantas et al., 2014). Also, biostimulants, mainly those based on seaweed extracts, has been used as an economically and ecologically alternative to fertilizers (Jayaraman et

$$
\text { al., } 2011) \text {. }
$$

Acadian ${ }^{\circledR}$ is a biostimulant based on Ascophyllum nodosum L. seaweed extract that is applied in plants to improve their growth and development because it synthesizes plant hormones and contains carbohydrates and macro and micronutrients (Silva et al., 2016). The effectiveness of using this biostimulant has already been shown in cashew (Anacardium occidentale L.) (Garcia et al., 2014) and grapevine (Vitis vinifera L.) (Ribeiro et al., 2017).

Thus, this work aimed to evaluate the use of Acadian ${ }^{\circledR}$ biostimulant in the growth of Formosa papaya seedlings irrigated with different concentrations of fishfarming wastewater.

\section{Material and Methods}

The experiment was carried out in a greenhouse at the Department of Agronomic and Forest Sciences, Federal Rural University of Semiarid (UFERSA), located in Mossoró city, Rio Grande do Norte State, Brazil (511'S, $37^{\circ} 20^{\prime} \mathrm{W}, 18 \mathrm{~m}$ above the sea level). The university is located in the Brazilian semiarid, where the climate is dry and very hot according to Köppen (BShw type) and presents $27.5{ }^{\circ} \mathrm{C}$ average annual temperature, $68.9 \%$ 
relative humidity, and $673.9 \mathrm{~mm}$ average annual rainfall (Espínola Sobrinho et al., 2011).

For seedling production, papaya seeds from Tainung-1 cultivar from the Formosa group were used. The seedlings were produced in polyethylene bags (15 $\mathrm{cm}$ by $25 \mathrm{~cm}$ in size) filled with a substrate composed of soil and organic compost at a 3:1 ratio by volume. Two seeds were sown per bag at $2 \mathrm{~cm}$ depth. At seven days after emergence, a thinning was performed, leaving only the most vigorous seedling.

The experimental design was completely randomized in a $2 \times 5$ factorial scheme, with four replicates. Factors corresponded to the use and non-use of biostimulant and five concentrations of wastewater $(0,10,20,30$, and $40 \%)$ diluted in potable water. The experimental unit consisted of ten seedlings, totaling 400 plants.

Wastewater was obtained from fish-farming located in the Aquaculture department from UFERSA and conditioned in $100 \mathrm{~L}$ plastic containers inside the greenhouse. Wastewater and potable water were diluted following the corresponding concentrations used as treatments, and a sample from each solution was taken for chemical analysis (Table 1). Irrigation with the solution was performed ten days after seed emergence applying $100 \mathrm{ml}$ per plant daily in each treatment.

Table 1. Chemical characterization of different dilutions of fish-farming wastewater with potable water.

\begin{tabular}{cccccccccc}
\hline \multirow{2}{*}{$\begin{array}{c}\text { Wastewater } \\
\text { concentration }\end{array}$} & $\mathrm{pH}$ & $\mathrm{CE}$ & $\mathrm{CO}_{3}$ & $\mathrm{HCO}_{3}$ & $\mathrm{Cl}$ & $\mathrm{Ca}+\mathrm{Mg}$ & $\mathrm{Ca}$ & $\mathrm{Na}$ & $\mathrm{K}$ \\
\cline { 7 - 11 }$\%$ & $\mathrm{H}_{2} \mathrm{O}$ & $\mathrm{dS} \mathrm{m} \mathrm{m}^{-1}$ & & & & $\mathrm{mg} \mathrm{dm}^{-3}$ & & & \\
\hline 0 & 7.85 & 0.53 & 1.10 & 2.95 & 2.50 & 1.56 & 0.63 & 9.75 & 10.35 \\
10 & 8.25 & 1.66 & 1.20 & 2.80 & 8.90 & 6.90 & 3.31 & 22.50 & 15.55 \\
20 & 8.15 & 3.29 & 0.70 & 2.85 & 15.90 & 12.14 & 6.13 & 31.65 & 20.25 \\
30 & 8.15 & 4.37 & 1.00 & 3.55 & 22.20 & 18.85 & 8.55 & 42.90 & 28.30 \\
40 & 8.25 & 8.76 & 1.10 & 3.30 & 29.00 & 24.87 & 11.04 & 53.40 & 36.90 \\
\hline
\end{tabular}

The biostimulant used in the experiment was based on $A$. nodosum seaweed extract (Acadian ${ }^{\circledR}$, Agritech, Canada). $12 \mathrm{ml}$ biostimulant was diluted in $3 \mathrm{~L}$ water, and $15 \mathrm{ml}$ of this solution was applied at the stem base by using a syringe. Applications were performed every seven days until the end of the experiment. Acadian had the following characteristics: 8.12, 6.82, $12.00,1.60,2.03$, and $8.16 \mathrm{~g} \mathrm{~kg}^{-1} \mathrm{~N}, \mathrm{P}, \mathrm{K}, \mathrm{Ca}, \mathrm{Mg}$, and $\mathrm{S}$, respectively; $5.74,13.60,11.5,0.04,24.40$, and $20,000 \mathrm{mg}$ $\mathrm{kg}^{-1} \mathrm{~B}, \mathrm{Cu}, \mathrm{Fe}, \mathrm{Mn}, \mathrm{Zn}$, and $\mathrm{Na}$ respectively; potassium hydroxide as $61.48 \mathrm{~g} \mathrm{~L}^{-1}$ water-soluble $\mathrm{K}_{2} \mathrm{O} ; 69.60 \mathrm{~g} \mathrm{~L}^{-1}$ total organic carbon; and $1.16 \mathrm{~g} \mathrm{dm}^{-3}$ density.

At 30 days after seed emergence, plant height $(\mathrm{cm})$ and root length $(\mathrm{cm})$ were measured by using a graduated ruler, and stem diameter $(\mathrm{mm})$ by using a digital calliper. Also, the number of fully expanded leaves was counted in each plant. Moreover, chlorophyll content index (CCl) was determined by using a digital chlorophyll meter in the five most vigorous plants of each treatment. Then, plants were separated into shoot and root, stored in paper bags, and dried in a forced circulation oven $\left(65^{\circ} \mathrm{C}\right.$, $72 \mathrm{~h}$ ) to determine the dry weight (g) of each plant organ on a precision analytical scale. Total dry weight (shoot dry weight plus root dry weight) was also determined, and results were expressed as g per plant. Subsequently, the ratio between plant height and stem diameter ( $\mathrm{PH}$ / $\mathrm{SD}$ ) and the ratio between shoot dry weight and root dry weight (SHDW/RDW) were calculated.
Statistical analysis was performed in SISVAR software (Ferreira, 2014). Data was submitted to analysis of variance by the $F$ test $(p<0.05)$. Means from qualitative treatments were compared by t-test ( $p<0.05$ ) and quantitative data were submitted to regression analysis.

\section{Results and Discussion}

Biostimulant doses significantly affected plant height, number of leaves, root length, plant height/ stem diameter ratio, and root dry weight/ shoot dry weight ratio. In turn, except by root length and chlorophyll content index, wastewater also affected the growth variables. Also, a significant interaction between the factors was observed for plant height, chlorophyll content index, root length, PH/SD, and SHDW/RDW (Table 2).

When treated with Acadian $^{\circledR}$, plants presented $18.90 \mathrm{~cm}$ height under any concentration wastewater used. However, without using the biostimulant, a quadratic fit was observed, in which a maximum of $24.35 \mathrm{~cm}$ height was reached at $9.95 \%$ wastewater concentration, decreasing afterwards (Figure 1A).

It was noted that the increased wastewater concentration linearly reduced stem diameter by $17.9 \%$ at $40 \%$ concentration when compared to $0 \%$ (control) (Figure 1B). On the other hand, plants showed a maximum number of leaves (10) at $10.68 \%$ wastewater concentration, not being affected by the use of biostimulant (Figure 1C). 
Table 2. Summary of analysis of variance and mean comparison test for the variables studied in papaya seedlings irrigated with wastewater and treated with Acadian $^{\circledR}$.

\begin{tabular}{|c|c|c|c|c|c|c|c|c|c|c|c|}
\hline \multirow{3}{*}{$S^{1}$} & \multirow{3}{*}{ DF } & \multicolumn{10}{|c|}{ Mean Square } \\
\hline & & $\mathrm{PH}$ & $R L$ & $\mathrm{NL}$ & SD & $\mathrm{CCl}$ & SHDW & RDW & TDW & $\mathrm{PH} / \mathrm{SD}$ & SHDW/RDW \\
\hline & & $\mathrm{cm}$ & $\mathrm{cm}$ & & $\mathrm{mm}$ & IFC & g & $\mathrm{g}$ & g & & \\
\hline Acadian (A) & 1 & $34.97^{*}$ & $130.32^{* *}$ & $4.62^{* *}$ & $0.44^{\mathrm{ns}}$ & $3.44^{\text {ns }}$ & $0.86^{\text {ns }}$ & $0.32^{\text {ns }}$ & $0.13^{\text {ns }}$ & $4.17^{* *}$ & $14.41^{* *}$ \\
\hline Wastewater (W) & 4 & $52.46^{* *}$ & $15.91^{\mathrm{ns}}$ & $2.61^{* *}$ & $0.63^{* *}$ & $1.65^{\mathrm{ns}}$ & $1.77^{* *}$ & $1.80^{* *}$ & $5.97^{* *}$ & $1.30^{* *}$ & $5.92^{* *}$ \\
\hline$A * W$ & 4 & $25.50^{* *}$ & $44.02^{* *}$ & $0.166^{\mathrm{ns}}$ & $0.36^{\text {ns }}$ & $6.98^{* *}$ & $0.61^{\mathrm{ns}}$ & $0.15^{\text {ns }}$ & $1.04^{\text {ns }}$ & $0.59^{*}$ & $2.28^{* *}$ \\
\hline Error & 30 & 5.33 & 6.92 & 0.31 & 0.17 & 1.14 & 0.33 & 0.12 & 0.68 & 0.21 & 0.51 \\
\hline Without Acadian & & $18.97 a^{2}$ & $24.87 b$ & $9.89 a$ & $4.22 a$ & $19.30 a$ & $3.04 a$ & $0.92 a$ & $3.96 a$ & $5.15 a$ & $3.94 a$ \\
\hline With Acadian & & $20.84 b$ & $28.48 a$ & $9.21 \mathrm{~b}$ & $4.01 a$ & $18.71 a$ & $2.74 a$ & $1.10 a$ & $8.85 a$ & $4.51 \mathrm{~b}$ & $2.74 b$ \\
\hline CV (\%) & & 11.6 & 9.86 & 5.88 & 10.14 & 5.61 & 19.81 & 34.93 & 21.05 & 9.60 & 21.27 \\
\hline
\end{tabular}
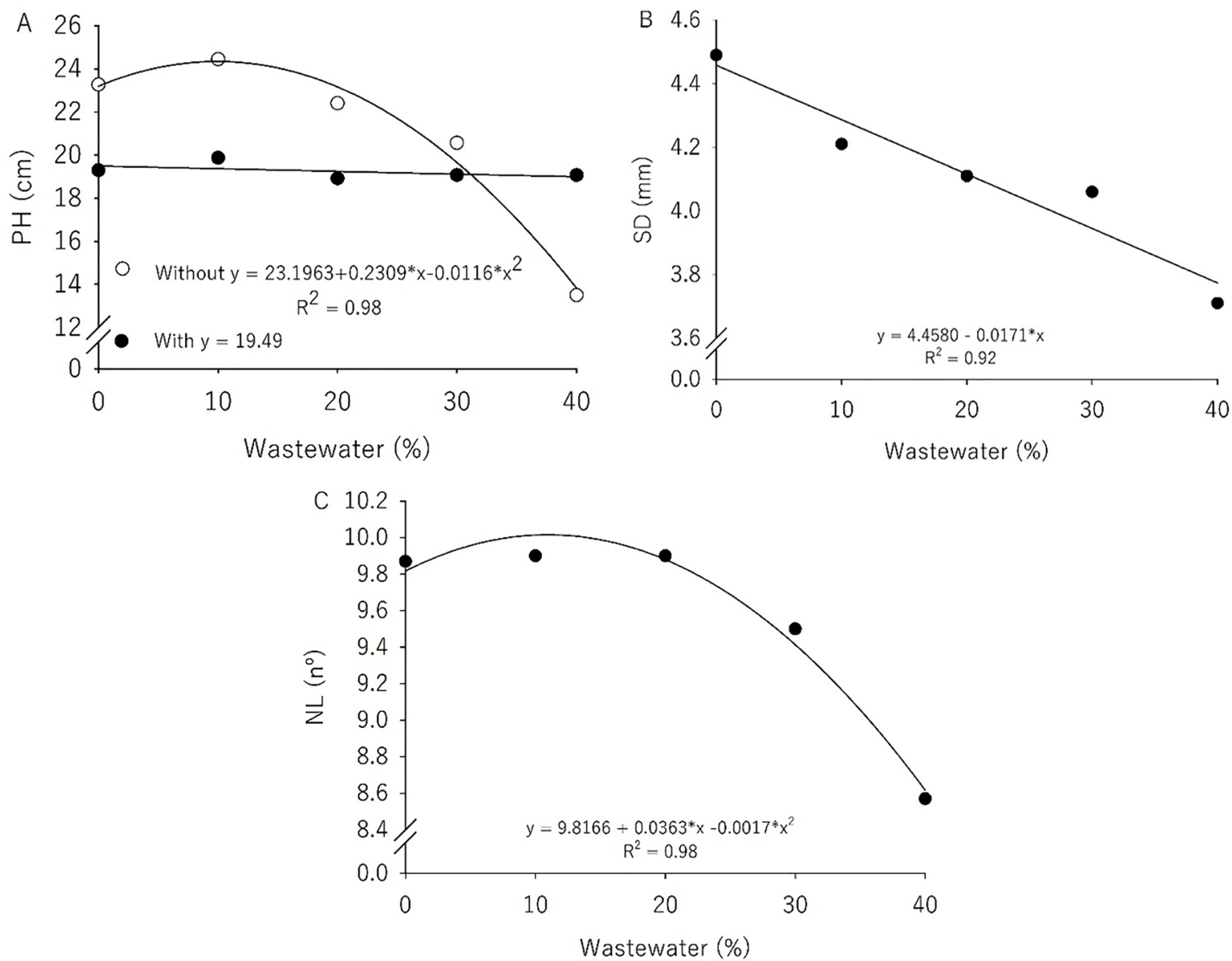

Figure 1. Plant height (PH; A), stem diameter (SD; B), and number of leaves (NL; C) in papaya (Carica papaya L.) seedlings irrigated with wastewater and with and without Acadian $^{\circledR}$ use.

Reduction in the growth components when high concentrations of wastewater were used may be due to the high amount of salts, mainly chlorine (Cl-) and sodium ( $\mathrm{Na}+$ ) in the water, as shown in Table 1. The high salt content in the irrigation water may cause hormonal imbalance in plants, as well as it may increase the production of reactive oxygen species which affect cell expansion and division and thus negatively affecting plant growth and development (Prisco et al., 2016). Negative effects of excessive salt content in both irrigation water and soil have been reported in fruit species (Bezerra et al.,
2019; Lima Neto et al., 2016).

In plants treated with the biostimulant, increased wastewater concentration did not affect PH/SD, which was 4.5 on average. However, without using the biostimulant, $\mathrm{PH} / \mathrm{SD}$ responded in a quadratic fit to the increase in wastewater concentration, with a maximum at $14.1 \%$ (Figure 2A). This behavior is according to the values obtained for $\mathrm{PH}$, and the decrease in SD. 

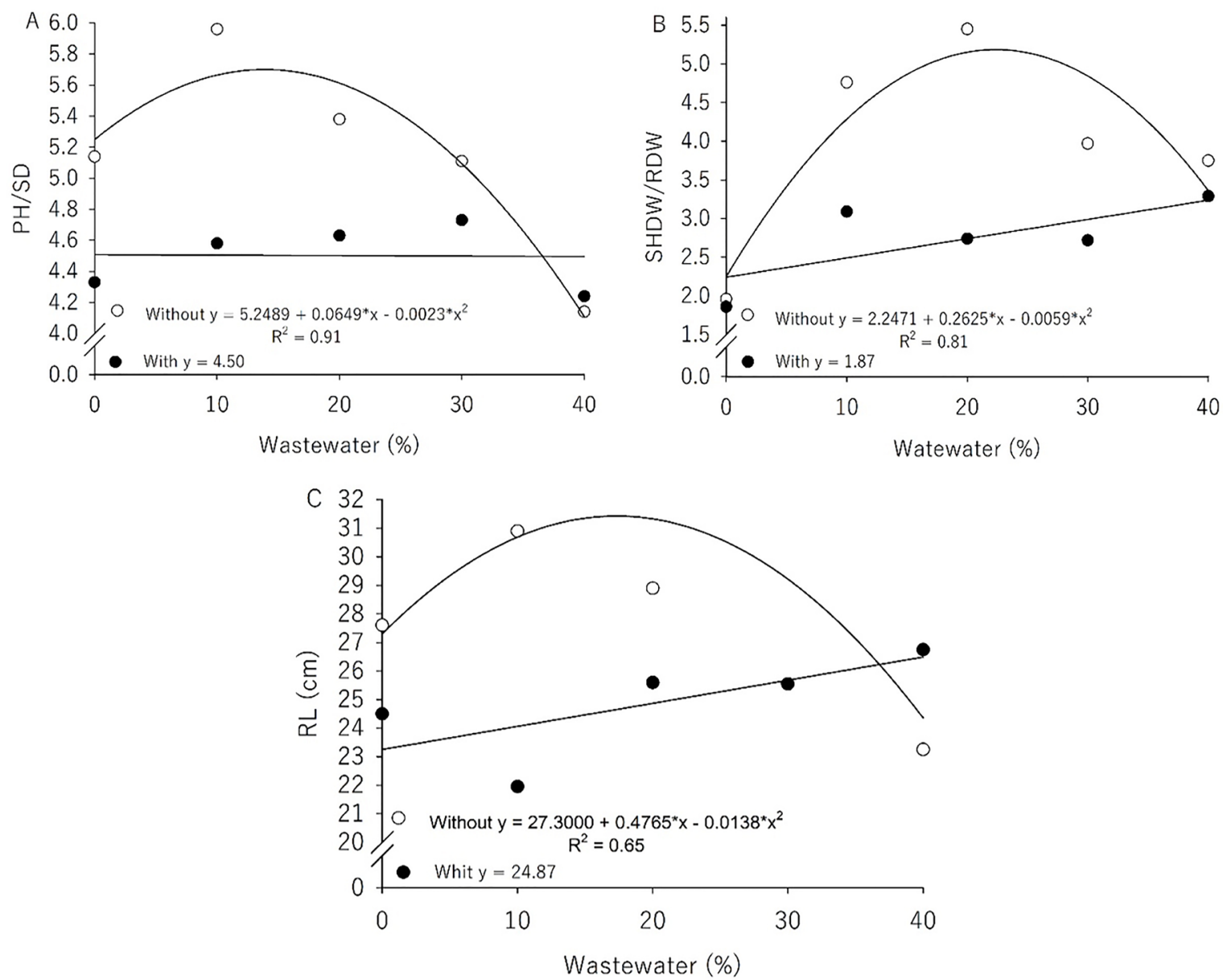

Figure 2. Plant height/ stem diameter ratio (PH/SD; A), shoot dry weight/ root dry weight ratio (SHDW/RDW; B), and root length (RL; C) in papaya (Carica papaya L.) seedlings irrigated with wastewater and with and without Acadian ${ }^{\circledR}$ use.

Also, without biostimulant use, SHDW/RDW and RL fitted a quadratic model, with maximums at 22.3 and $17.3 \%$ wastewater concentration, respectively. On the other hand, with biostimulant use, such variables did not respond to increased wastewater concentration (Figures $2 \mathrm{~B}$ and $2 \mathrm{C}$ ). As such variables responded similarly to wastewater, it suggests they were strongly correlated.

As shown in Table 1, electrical conductivity increased markedly with the increase in wastewater concentration, ranging from 3.29 (at 20\%) to 8.76 dS m-1 (at $40 \%$ ). Thus, such an increase in water salinity used for irrigation may be responsible for the reduction in growth variables, as mentioned above. It occurs because excessive salt concentration reduces water content in plant tissues and consequently reduce cell wall expansion which thus inhibits plant growth (Souza et al., 2017).

For biomass, SHDW, RDW and TDW decreased $32.1,52.7$, and $40.9 \%$, respectively, with the increase in wastewater concentration (Figures 3A, 3B and 3C).

Under salt stress conditions, plants close stomata as a first defense mechanism to avoid water loss. However, it consequently reduces the photosynthetic rate, which thus limits photoassimilate supply to shoot and root, declining plant dry matter production (Kawavata et al., 2017). Similar results were reported by Sá et al. (2013) in papaya seedlings (Carica papaya L.) and Santos et al. (2018) in sunflower plants (Helianthus annuus L.) under salt stress conditions.

Without biostimulant, $\mathrm{CCl}$ responded in a quadratic fit with the increase in wastewater concentration, with a maximum at $16.7 \%$, above which decreased significantly (Figure 3D). Salinity may cause such a reduction. In plants, salinity reduces chlorophyll synthesis as well as increases chlorophyllase enzyme activity, which degrades chlorophyll molecules (Houimili et al., 2010).

On the other hand, in plants treated with the biostimulant, $\mathrm{CCl}$ linearly increased with increasing wastewater concentration, in which $\mathrm{CCl}$ was $11.7 \%$ more at $40 \%$ compared to 0\% (Figure 3D). Such a beneficial effect may be due to seaweed extract-based biostimulants contain substances such as amino acids and nutrients, which in contact with plants can stimulate enzyme as well as chlorophyll production, and act on the hormonal balance (Matoso \& Kusdra, 2014). 

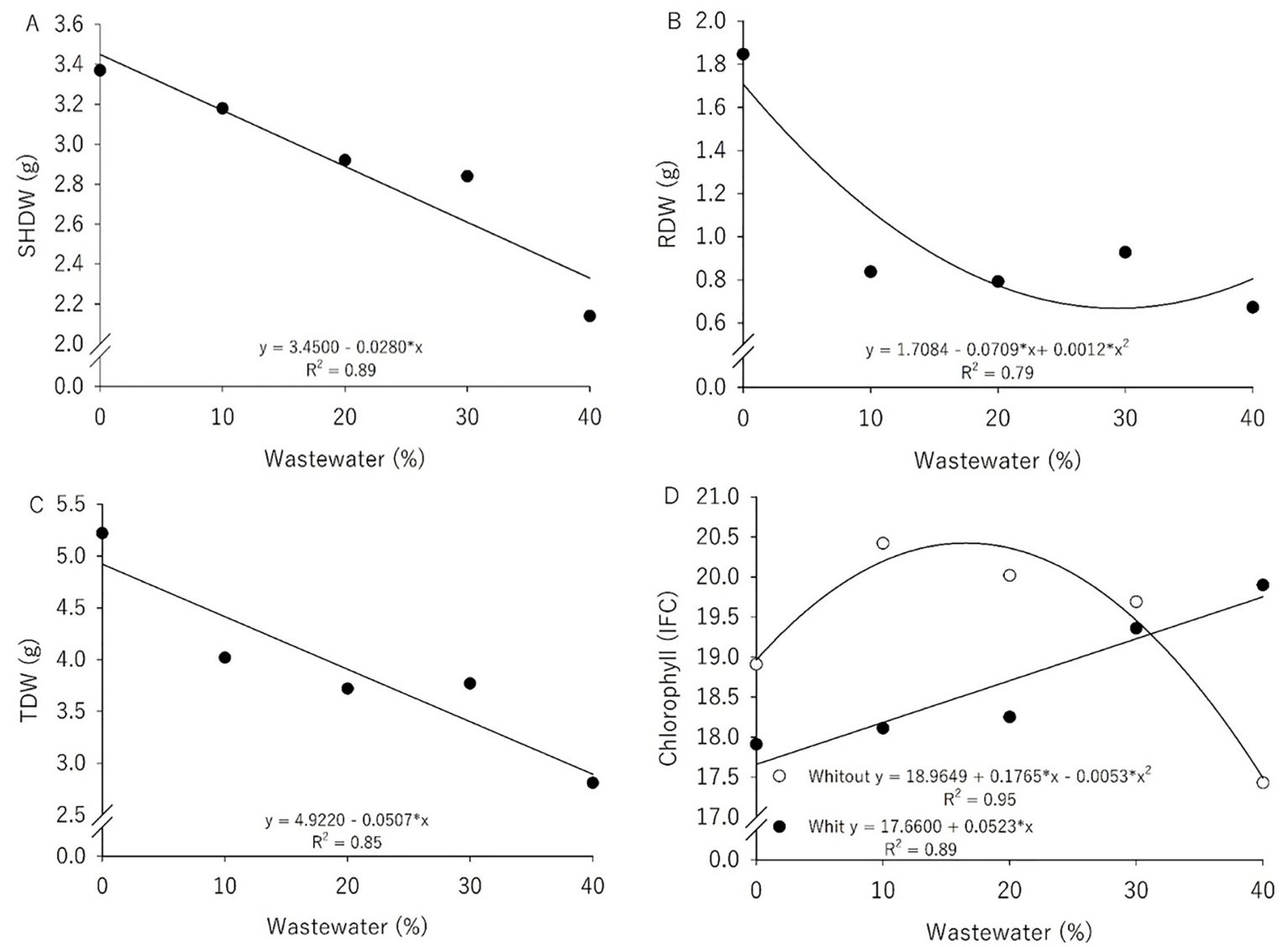

Figure 3. Shoot dry weight (SHDW; A), root dry weight (RDW; B), total dry weight (TDW; C), and chlorophyll content index (CCl; D) in papaya (Carica papaya L.) seedlings irrigated with wastewater and with and without Acadian ${ }^{\circledR}$.

\section{Conclusions}

High concentrations of fish-farming wastewater negatively affect the production of Formosa papaya seedlings.

Seaweed based-biostimulant $\quad\left(\right.$ Acadian $\left.^{\circledR}\right)$ positively influenced chlorophyll content.

\section{Acknowledgments}

The authors thank the Coordenação de Aperfeiçoamento de Pessoal de Nível Superior (CAPES) and the Conselho Nacional de Desenvolvimento Científico e Tecnológico (CNPq), Brazil, for the research funding.

\section{References}

Anuário Brasileiro de Fruticultura. 2018. Gazeta, Santa Cruz do Sul, Brazil. 88p.

Batista, R.O., Martinez, M.A., Paiva, H.N., Batista, R.O., Cecon, P.R. 2014. O efeito da água residuária da suinocultura no desenvolvimento e qualidade de mudas de Eucalyptus uropgylla. Ciência Florestal 24: 127-135.

Bezerra, M.A.F., Pereira, W.E., Bezerra, F.T.C., Cavalcante, L.F., Medeiros, S.A.S. 2019. Nitrogen as a mitigator of salt stress in yellow passion fruit seedlings. Semina: Ciências Agrárias 40: 611-622.
Dantas, I.L.A., Faccioli, G.G., Mendonça, L.C., Nunes, T.P., Viegas, P.R.A., Santana, L.O.G. 2014. Viabilidade do uso de água residuária tratada na irrigação da cultura do rabanete (Raphanus sativus L.). Revista Ambiente \& Água 9: 110-117.

Espínola Sobrinho, J., Pereira, V.D.C., Oliveira, D.D., Santos, W.D.O., Cavalcanti, N.K., Maniçoba, R.M. 2011. Climatologia da Precipitação no Município de Mossoró - RN, In: XVII Congresso Brasileiro de Agrometeorologia, Guarapari, Brazil. 4 p.

Ferreira, D.F. 2014. Sisvar: A Guide for its Bootstrap procedures in multiple comparisons. Ciência e Agrotecnologia 38: 10-17.

Figueiredo, L.F., Maia Júnior, S.O., Ferraz, R.L.S., Dutra, A.F., Bezerra, J.D., Melo, A.S. 2018. Crescimento e partição de massa seca em mudas de mamoeiro sob estresse salino. Revista Brasileira de Agricultura Irrigada 12: 2984-2990.

Garcia, K.G.V., Silva, C.P., Cunha, C.S.M., Nascimento, C.D.V., Tosta, M.S. 2014. Extrato da alga Ascophyllum nodosum (L.) no desenvolvimento de porta-enxertos de cajueiro. Enciclopédia Biosfera 10:1706-1715.

Houimli, S.I.M., Denden, M., Mouhandes, B.D. 2010. Effects of 24-epibrassinolide on growth, chlorophyll, electrolyte leakage and proline by pepper plants under $\mathrm{NaCl}^{-}$ stress. EurAsia Journal of BioSciences 4: 96-104. 
Jayaraman, J., Norrie, J., Punja, Z.K. 2011. Commercial extract from the brown seaweed Ascophyllum nodosum reduces fungal diseases in greenhouse cucumber. Journal of Applied Phycology 23: 353-361.

Kawavata, C.K.H., Fois, D.A.F., Coppo, J.C., Neto, A.A. 2017. Influência de doses e de duas fontes de potássio no sistema radicular do milho e na condutividade elétrica no solo. Investigación Agraria 19: 28-34.

Lima Neto, A.J., Cavalcante, L.F., Mesquita, F.O., Souto, A.G.L., Santos, G.P., Santos, J.Z., Mesquita, E.F. 2016. Papaya seedlings irrigation with saline water in soil with bovine biofertilizer. Chilean Journal of Agricultural Reseach 76: 236-242.

Matoso, S.C.G., Kusdra, J.F. 2014. Nodulação e crescimento do feijoeiro em resposta à aplicação de molibdênio e inoculante rizobiano. Revista Brasileira de Engenharia Agrícola e Ambiental 18: 567-573.

Oliveira, M.L.A., Paz, V.P.S., Gonçalves, K.S., Oliveira, G.X.S. 2017. Crescimento e produção de girassol ornamental irrigado com diferentes lâminas e diluições de água residuária. Irriga 22: 204-219.

Prisco, J.T., Gomes Filho, E.G., Miranda, R.S. 2016. Physiology and biochemistry of plants growing under salt stress. In: Gheyi, H.R., Dias, N.S., Lacerda, C.F., Gomes Filho, E. 2016. Manejo da salinidade na agricultura: estudos básicos e aplicados. INCTSal, Fortaleza, Brazil. p. 163-180.

Ribeiro, R.F., Lobo, J.T., Cavalcante, I.H.L., Tenreiro, I.G.P., Lima, D.D. 2017. Bioestimulante na produção de mudas de videira cv. Crimson Seedless. Revista Scientia Agraria 18: $36-42$.

Sá, F.V.S., Brito, M.E.B., Melo, A.S., Antônio Neto, P., Fernandes, P.D., Ferreira, I.B. 2013. Produção de mudas de mamoeiro irrigadas com água salina. Revista Brasileira de Engenharia Agrícola e Ambiental 17:1047-054 .

Santos, S.C., Guerrero, A.C., Lima, A.S., Fátima, R.T., Abrantes, J.V., Brito, M.E.B., Fernandes, A.V.F., Sousa, E.P.R. 2018. Growth and production of cultivars ornamental sunflower irrigated with water of different salinities. Journal of Agricultural Science 10: 378-387.

Silva, C.C., Arrais, I.G., Almeida, J.P.N., Dantas, L.L.G.R., Silva, F.S.O., Mendonça, V. 2016. Extrato de alga Ascophyllum nodosum (L.) Le Jolis na produção de porta-enxertos de Anonna glabra L. Revista de Ciências Agrárias 39: 234-241.

Souza, L.P., Nobre, R.G., Silva, E.M., Gheyi, H.R., Soares, L.A. 2017. Produção de portaenxerto de goiabeira cultivado com águas de diferentes salinidades e doses de nitrogênio. Revista Ciência Agronômica 48: 596-604.

Conflict of Interest Statement: The authors declare that the research was conducted in the absence of any commercial or financial relationships that could be construed as a potential conflict of interest.

All the contents of this journal, except where otherwise noted, is licensed under a Creative Commons Attribution License attribuition-type BY. 